\title{
Convergence of Russian Regions: Different Patterns for Poor, Middle and Rich
}

The Strategy of Spatial Development of the Russian Federation until 2025 aims at the economic growth acceleration and reduction of the intra-regional socio-economic differences. Therefore, the factors affecting the economic growth of regions, convergence of regions, spillover effects from the neighbouring regions are of importance. Russian regions are very different and do not converge to a unique equilibrium path. 80 Russian regions were divided into the groups of poor, middle and rich regions. Three main hypotheses were considered, based on the differences in the 1) convergence speed, 2) influence of the same factors, 3) different mutual influence of regions. They were tested using a modified spatially autoregressive model for the three groups using the Russian regional data for 2000-2017. Beta-convergence was found only for the middle and rich regions, the rate of convergence was higher in the rich regions. The poor regions did not grow faster than the other regions, confirming the relevance of the Strategy of Spatial Development. The similarities and differences were identified in the factors ensuring the economic growth of regions belonging to the three groups. The growth in all regions is stimulated by the regional economy openness. The growth of rich regions can be achieved by increasing the investment and reducing the investment risk. However, the investments in the poor and middle regions are not effective. The poor and middle regions receive positive spillovers from the growth of the neighbouring regions. It is possible to expect reduced differences in the living standards between the poor and rich regions. ${ }^{2}$

Keywords: Russian regions, convergence, conditional convergence, gross regional product, economic growth, spatial-econometrics models, spatial effects, poor regions, rich regions, economic growth

For citation: Demidova, O. A. (2021). Convergence of Russian Regions: Different Patterns for Poor, Middle and Rich. Ekonomika regiona [Economy of regions], 17(4), 1151-1165, https://doi.org/10.17059/ekon.reg.2021-4-8

\footnotetext{
1 (c) Demidova O. A. Text. 2021.

${ }^{2}$ The preliminary version of this research entitled "Uneven development of emerging countries on the example of Russia" for 20002014 period data was presented at the AISSEC XXth Scientific Conference "Rise and decline of economics: a comparative perspective", October 4-5, 2018, Turin, Italy, the Collegio Carlo Alberto, the proceedings are available by link https://www.osservatorio-economie-emergenti-torino.it/images/November_2018/Newsletter_10-November_2018_1.pdf, p. 11.
} 
Национальный исследовательский университет «Высшая школа экономики», Москва, Российская Федерация https://orcid.org/0000-0001-5201-3207,e-mail: demidova@hse.ru

\section{Различные модели конвергенции бедных, средних и богатых регионов России}

Стратегия пространственного развития Российской Федерации на период до 2025 года нацелена на ускорение экономического роста и сокращение внутрирегиональных социально-экономических различий. Важную роль играют факторы, влияющие на региональный экономический рост, конвергенцию и спилловер-эффекты от соседних регионов. Поскольку российские регионы значительно различаются между собой, нет единой траектории их развития. 80 субъектов Российской Федерации были поделены на 3 группы - бедные, средние и богатые регионов. В статье были проанализированы три основные гипотезы, основанные на различиях: 1) в скорости конвергенции, 2) во влиянии одних и тех же факторов, 3) во влиянии регионов друг на друга. Представленные гипотезы были протестированы с помощью модифицированной пространственно-авторегрессионной модели для трех выделенных групп на основе данных по регионам России за 2000-2017 г2. Бета-конвергенция была обнаружена только в средних и богатых регионах, причем в богатых регионах скорость конвергенции выше. Рост бедных регионов не превышает рост других субъектов, что подтверждает актуальность Стратегии пространственного развития. Были выявлены сходства и различия факторов, обеспечивающих экономический рост регионов всех трех групп. Обнаружено, что открытость региональной экономики стимулирует рост во всех исследованных регионах. Рост богатых регионов может быть достигнут за счет увеличения инвестиций и снижения инвестиционного риска, в то время как инвестиции в бедные и средние регионы неэффективны. Спилловер-эффекты, возникающих при росте соседних субъектов, положительно влияют на бедные и средние регионы. В дальнейшем можно ожидать сокращения разрыва в уровне жизни населения бедных и богатых регионов.

Ключевые слова: российские регионы, конвергенция, условная конвергенция, валовой региональный продукт, экономический рост, пространственно-эконометрические модели, пространственные эффекты, бедные регионы, богатые регионы, экономический рост

Для цитирования: Демидова О. А. Различные модели конвергенции бедных, средних и богатых регионов России. 2021. Т. 17, вып. 4. С. 1151-1165. https://doi.org/10.17059/ekon.reg.2021-4-8.

\section{Introduction}

The factors that determine economic growth, convergence or divergence of Russian regions have been of interest for researchers and remained relevant over the last 20 years. The results often depend substantially on the chosen time interval. In my opinion, the period of 2000-2017 chosen in this study is insufficiently studied. At the same time, Russian regions differ essentially in terms of geography, climate, and endowment with natural resources that is noted by many authors [1-2]. Their economic development differs accordingly; therefore, the state regional policy of the Russian Federation until 2020 focus on (i) reducing interregional differences and (ii) achieving a balanced socio-economic regional development.

According to Glushenko [2], Russian regions characterised by increased diversity do not converge to the unique equilibrium path. Therefore, many researchers split Russian regions into several groups (that are similar in some indicators) with respect to which we can assume convergence to the equilibrium path or divergence trends. The methods of separation into such groups are very different and are described in more detail in the next section. The models for each of the selected groups of regions are frequently estimated separately (for example, for the western and eastern regions or for rich and poor regions, etc.). Spatial effects reflecting the mutual influence of regions from different groups on each other are often not taken into account, which may lead to a bias in the estimates of the coefficients, especially the beta coefficients, characterising the speed of the convergence process [3-4]. In this paper, after analysing the density of the regions' distribution by income per capita, it was decided to divide the regions into three groups (poor, middle and rich) and find out what factors affect economic growth in these groups of regions and whether beta-convergence is observed. At the same time, the mutual influence of the regions on each other was taken into account.

The next section provides a brief literature review of papers devoted to the modelling of the processes convergence/divergence of Russian regions. In the third section, I formulate three main research hypotheses, present my data sources, and 
discuss the choice of the model and explanatory variables. The forth section sets out the results of the estimation and interpretation. The last section contains some concluding remarks and policy implications.

\section{Literature Review}

The heterogeneity of Russian regions leads to the fact that absolute convergence models are not suitable for modelling the processes of convergence/divergence of Russian regions, and so it is necessary to use conditional convergence models. Therefore, in this brief review of the works devoted to the modelling of the processes of convergence/divergence of Russian regions, I will focus in greater detail onmore or less homogeneous groups of Russian regions that were singled-out by other researchers, and also factors that affect their economic growth, including those which reflected the influence of other regions.

Guriev and Vakulenko [5] found no convergence of Russian regions in the 1990s. After 2000, the situation changed, labour and capital mobility increased, that allowed the poor Russian regions to get out of the poverty traps, meaning that they were no longer so different from the rich regions. Berkowitz and DeJong [6] also did not reveal convergence of Russian regions for the period 1993-2000. The results of the same authors [7] for the period 20002007 differed from the earlier one: the coefficients at the initial level of income were negative, but their significance depended on the choice of the model. According to the results in [6] and [7], the main driver of economic growth in the period 1993-2000 was entrepreneurial activity, and in the period 20002007 it was the emergence of bank-issued credit.

Many authors have noted the need to take into account the quality of regional institutions when modelling economic growth. Leonard, Nazarov and Vakulenko [8] used the RA Expert investment risk index as such an indicator. Alexeev and Chernyavskiy [9] also used this index and additionally took "Carnegie Center corruption control index". Libman [10] applied an index developed by Vainberg and Rybnikova [11] and based the research on a survey of small and medium enterprises in 2005.

The authors of the above papers often included the distance to Moscow or to the regional capital as the explanatory variables. However, this inclusion did not allow them to take into account the mutual influence of the other regions. This can be done better by using spatial-econometric models. The description of such models could be found in [12].

Buccellato [13] and Lugovoy [14] were among the first authors who substantiated the need to take into account the mutual influence of regions when modelling economic growth in Russian regions. Buccellato [13] found spatial effects for 1999-2004 regional data. He stressed that spatial factors cannot be neglected. Otherwise, the rate of convergence is overestimated. Lugovoy [14], using data for 79 regions for 1998-2004, also revealed the existence of spatial relationships between Russian regions. However, he noted that the intensity of these relationships is significantly lesser in comparison with European ones due to longer distances and weaker transport infrastructure.

However, Russia is a large and heterogeneous country, meaning that dependencies may differ for different groups of its regions, including the issues of convergence. Kolomak [15], according to the data for 1996-2008, estimated the models separately for the western and eastern regions. Convergence was found for both groups of regions, but its rate was higher for the western regions. In addition, the western regions received positive spillovers from the development of neighbouring regions, and the eastern regions received negative ones.

Most researchers identified two groups of regions: rich and poor. However, in some works the number of such groups increases. For example, Bufetova [16] for data of 2000-2014 split all Russian regions into 5 groups depending on GRP, but noted that in the balance the number of different groups of regions is reduced. Zubarevich and Gorina [17] also divided regions into 5 groups by the condition of their budgets. However, the authors of the last two studies did not set themselves the task of identifying factors that affect the development dynamics of the groups of regions that they have identified.

In the current research, I tried to develop the ideas of the above-mentioned authors about the heterogeneity of Russian regions and possible differences in the processes occurring in them, and take into account the mutual influence of different regions on each other. All regions of Russia were divided into three groups (poor, middle, and rich, the choice of three groups is justified below), and the processes of conditional beta-convergence for the selected groups are studied. Factors that reflect the influence of the regions on each other are included among the factors influencing the growth rate of the selected groups of regions.

\section{Data and Methodology}

\section{Data}

The research sample consists of 80 regions analysed in the period from 2000 to 2017 . These 
Table 1

United constituent entities of the Russian Federation

\begin{tabular}{|c|c|c|}
\hline Data & Merging regions & Incorporated as \\
\hline \multirow{3}{*}{01.01 .2007} & $\begin{array}{l}\text { Taymyr Autonomous } \\
\text { Okrug }\end{array}$ & \multirow{3}{*}{ Krasnoyarsk krai } \\
\hline & $\begin{array}{l}\text { Evenk Autonomous } \\
\text { Okrug }\end{array}$ & \\
\hline & Krasnoyarsk krai & \\
\hline \multirow[b]{2}{*}{ 01.07.2007 } & Kamchatka oblast & \multirow[b]{2}{*}{ Kamchatka krai } \\
\hline & $\begin{array}{l}\text { Koryak Autonomous } \\
\text { Okrug }\end{array}$ & \\
\hline \multirow[t]{2}{*}{01.01 .2008} & $\begin{array}{l}\text { Ust-Orda Buryat } \\
\text { Autonomous Okrug }\end{array}$ & \multirow[t]{2}{*}{ Irkutsk oblast } \\
\hline & Irkutsk oblast & \\
\hline \multirow[b]{2}{*}{01.03 .2008} & Chita oblast & \multirow[b]{2}{*}{ Zabaykalsky krai } \\
\hline & $\begin{array}{l}\text { Agin-Buryat } \\
\text { Autonomous Okrug }\end{array}$ & \\
\hline \multirow{2}{*}{ 01.07.2012 } & Moscow & \multirow{2}{*}{ Moscow } \\
\hline & Moscow oblast & \\
\hline
\end{tabular}

data are available for public access at the website of the Federal State Statistics Service (www.gks. $\mathrm{ru}$ ) of the Russian Federation. Data on some regions is missing (the Republic of Chechnya, the Republic of Crimea and Sevastopol). In addition, Kaliningrad oblast was not included in the study because it has no common borders with other Russian regions. Tyumen oblast was considered without the Khanty-Mansi Autonomous Okrug - Yugra and Yamalo-Nenets Autonomous Okrug, Arkhangelsk oblast was considered without the Nenets Autonomous Okrug.

During the reporting period, some regions underwent administrative changes. This alteration of boundaries was taken into consideration and mitigated by an aggregating procedure (see Table 1).

One of the main variables used in the performed analysis is the logarithm of gross regional product (GRP) per capita in basic prices of 2000. Gross regional product was adjusted for the difference in the cost of the fixed basket of consumer goods and services. For example, if for a certain region the cost of the fixed basket was 0.87 of the Russian average, GRP per capita for the region was divided by 0.87. Similar conversions were made for each region. This adjustment was carried out before the division of regions into groups.

As noted in the surveyed literature, many authors stated that the processes occurring in Russian regions are often different. In some groups of regions, convergence processes may occur, and in others - divergence. In order to select the optimal number of clusters for Russian regions, a kernel density estimation of the logarithm of GRP per capita in 2000 adjusted for different purchasing power was used (see Fig. 1).

This graph shows that Russian regions should be divided into three groups. This division was made on the basis of the classification of the regions proposed by Zubarevich and Gorina [17], outstanding experts of Russian regions. The authors divided regions into 5 groups according to their budget sufficiency and the state of their budgets: rich, more responsible, middle, poor, and default. However, modelling the interaction of the five groups of regions is somewhat difficult. Some groups of regions have a number of similarities that allow researchers to unify them. To facilitate the technical side of the research, regions with sufficient transfers from the federal centre, and "default" regions were aggregated into the "poor" regions group, the "middle" and "more responsible" regions were aggregated into "middle regions", with the "rich" regions remained the same group. Table 2 shows the list of regions included in these groups.

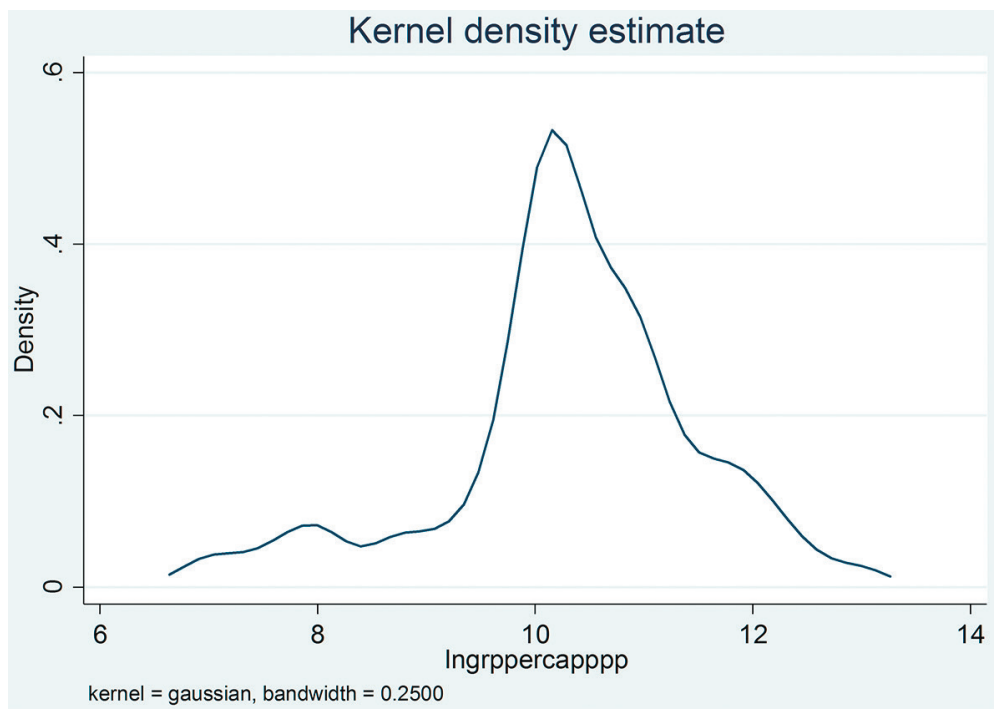

Fig. 1. Kernel density of the logarithm of GRP per capita in 2000 adjusted for different purchasing power In(grppercapppp) 
List of Russian regions

\begin{tabular}{|c|c|c|}
\hline Poor regions & Middle regions & Rich regions \\
\hline 1. Belgorod oblast & 28. Arkhangelsk oblast without NAO & 73. Nenets Autonomous Okrug (NAO) \\
\hline 2. Kostroma oblast & 29. Bryansk oblast & 74. Moscow + Moscow oblast \\
\hline 3. Orel oblast & 30. Vladimir oblast & 75. Leningrad oblast \\
\hline 4. Ryazan oblast & 31. Voronezh oblast & 76. Saint-Petersburg \\
\hline 5. Smolensk oblast & 32. Ivanovo oblast & $\begin{array}{l}\text { 77. Tyumen oblast without Autonomous } \\
\text { Okrugs }\end{array}$ \\
\hline 6. Republic of Karelia & 33. Kaluga oblast & 78. Khanty-Mansi Autonomous Okrug \\
\hline 7. Vologda oblast & 34. Kursk oblast & 79. Yamalo-Nenets Autonomous Okrug \\
\hline 8. Novgorod oblast & 35. Lipetsk oblast & 80. Sakhalin oblast \\
\hline 9. Pskov oblast & 36. Tambov oblast & \\
\hline 10. Republic of Kalmykia & 37. Tver oblast & \\
\hline 11. Krasnodar krai & 38. Tula oblast & \\
\hline 12. Republic of Dagestan & 39. Yaroslavl oblast & \\
\hline 13. Republic of Ingushetia & 40. Komi Republic & \\
\hline 14. Republic of Kabardino-Balkaria & 41. Murmansk oblast & \\
\hline $\begin{array}{l}\text { 15. Republic of } \\
\text { Karachaevo-Cherkessia }\end{array}$ & 42. Republic of Adygea & \\
\hline $\begin{array}{l}\text { 16. Republic of Northern Osetia } \\
\text { - Alania }\end{array}$ & 43. Astrakhan oblast & \\
\hline 17. Republic of Mari El & 44. Volgograd oblast & \\
\hline 18. Republic of Mordovia & 45. Rostov oblast & \\
\hline 19. Republic of Udmurtia & 46. Stavropol krai & \\
\hline 20. Kirov oblast & 47. Republic of Bashkortostan & \\
\hline 21. Penza oblast & 48. Republic of Tatarstan & \\
\hline 22. Saratov oblast & 49. The Chuvash Republic & \\
\hline 23. Altai Republic & 50. Perm krai & \\
\hline 24. Republic of Tuva & 51. Nizhny Novgorod oblast & \\
\hline 25. Zabaykalsky krai & 52. Orenburg oblast & \\
\hline 26. Amur oblast & 53. Samara oblast & \\
\hline \multirow[t]{19}{*}{ 27. Chukotka Autonomous Okrug } & 54. Ulyanovsk oblast & \\
\hline & 55. Kurgan oblast & \\
\hline & 56. Sverdlovsk oblast & \\
\hline & 57. Chelyabinsk oblast & \\
\hline & 58. Republic of Buryatia & \\
\hline & 59. Republic of Khakassia & \\
\hline & 60. Altai Krai & \\
\hline & 61. Krasnoyarsk Krai & \\
\hline & 62. Irkutsk oblast & \\
\hline & 63. Kemerovo oblast & \\
\hline & 64. Novosibirsk oblast & \\
\hline & 65. Omsk oblast & \\
\hline & 66. Tomsk oblast & \\
\hline & 67. Republic of Sakha (Yakutia) & \\
\hline & 68. Kamchatka krai & \\
\hline & 69. Primorsky Krai & \\
\hline & 70. Khabarovsk Krai & \\
\hline & 71. Magadan oblast & \\
\hline & 72. Jewish Autonomous oblast & \\
\hline
\end{tabular}




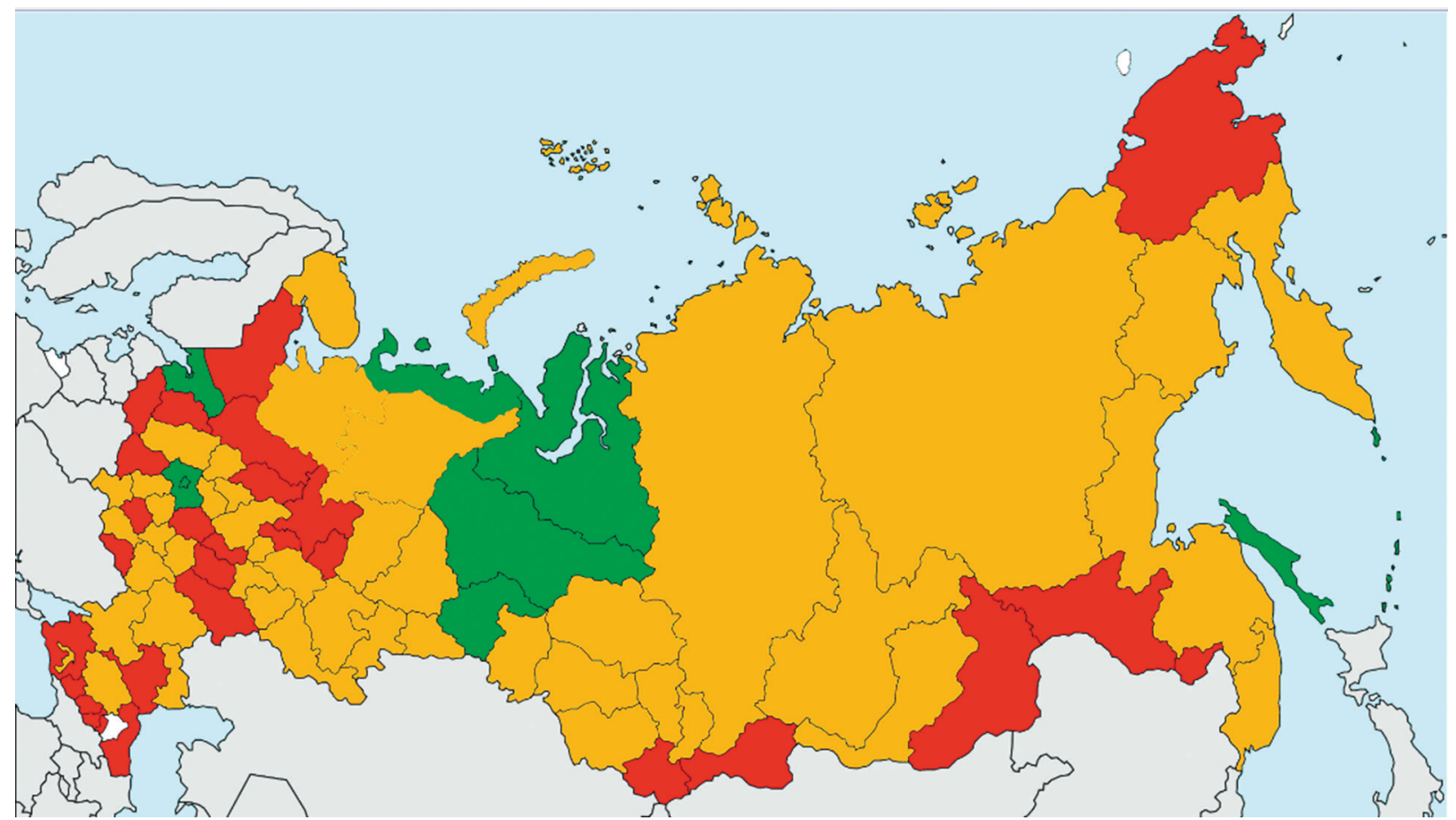

Fig. 2. Map of Russia (poor, middle and rich regions are coloured red, yellow and green correspondingly)

In Figure 2, these groups are painted in different colours.

The group of eight rich regions includes Moscow, St. Petersburg and adjacent areas, as well as the resource-rich regions of Nenets Autonomous Okrug, Khanty-Mansi Autonomous Okrug, Tyumen region, YamaloNenets Autonomous Okrug, and Sakhalin oblast. The group of 27 poor regions (with highly-subsidised regions) includes southern Russian regions, North Caucasus, some regions of the cen- tral part of Russia, and Chukotka Autonomous Okrug.

The 3-year average growth rate of GRP per capita (in logarithm) was compared for each of the selected groups of regions (see Fig. 3).

The average 3-year period was used to avoid sharp fluctuations in the values of the dependent variable that arise for some regions when using growth data for one year. The graph shows that the growth rates for the rich regions, since 2005, have significantly slowed down compared to the

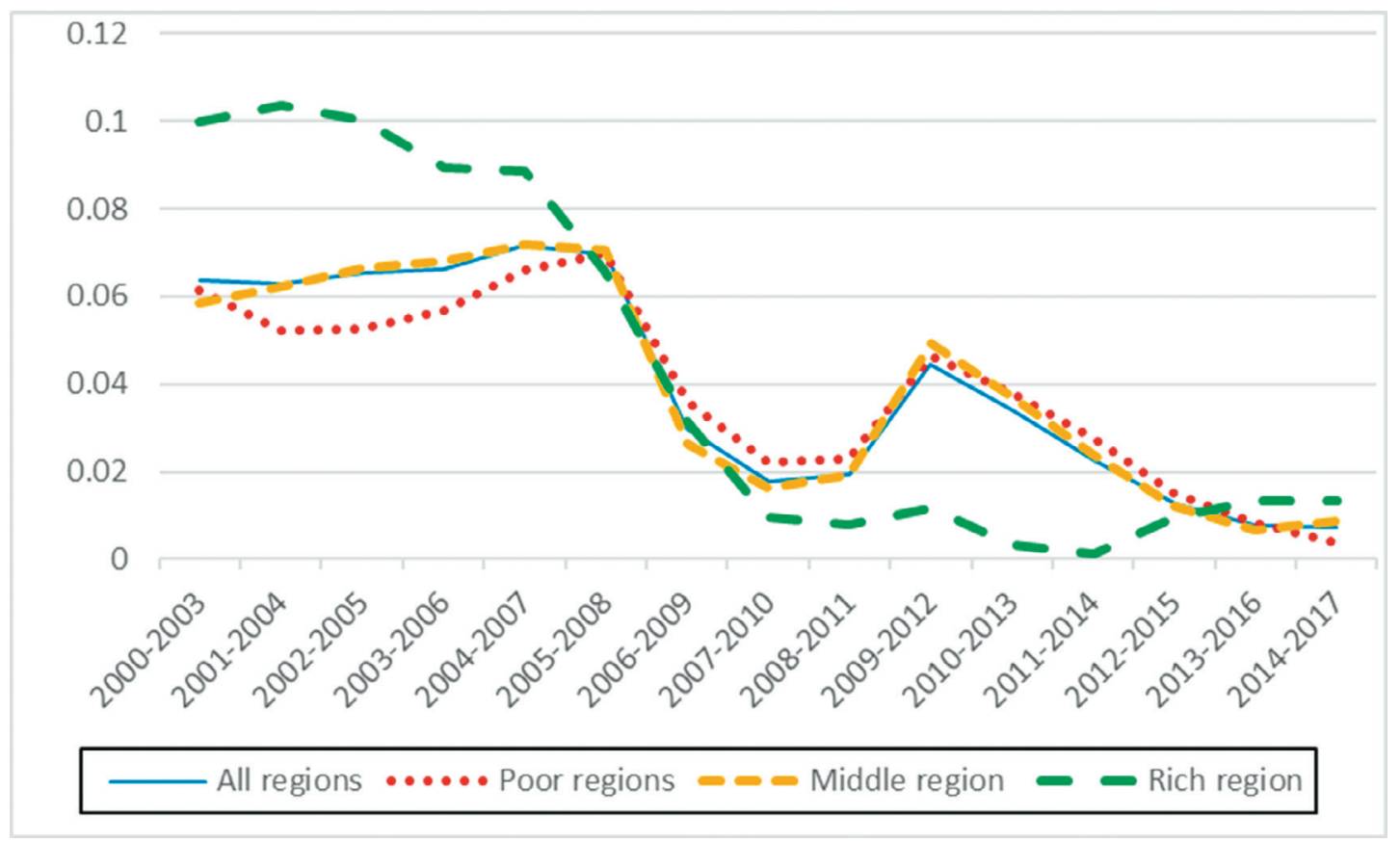

Fig. 3. On the vertical axis - the average GRP growth for the corresponding three-year period (in logarithms) 


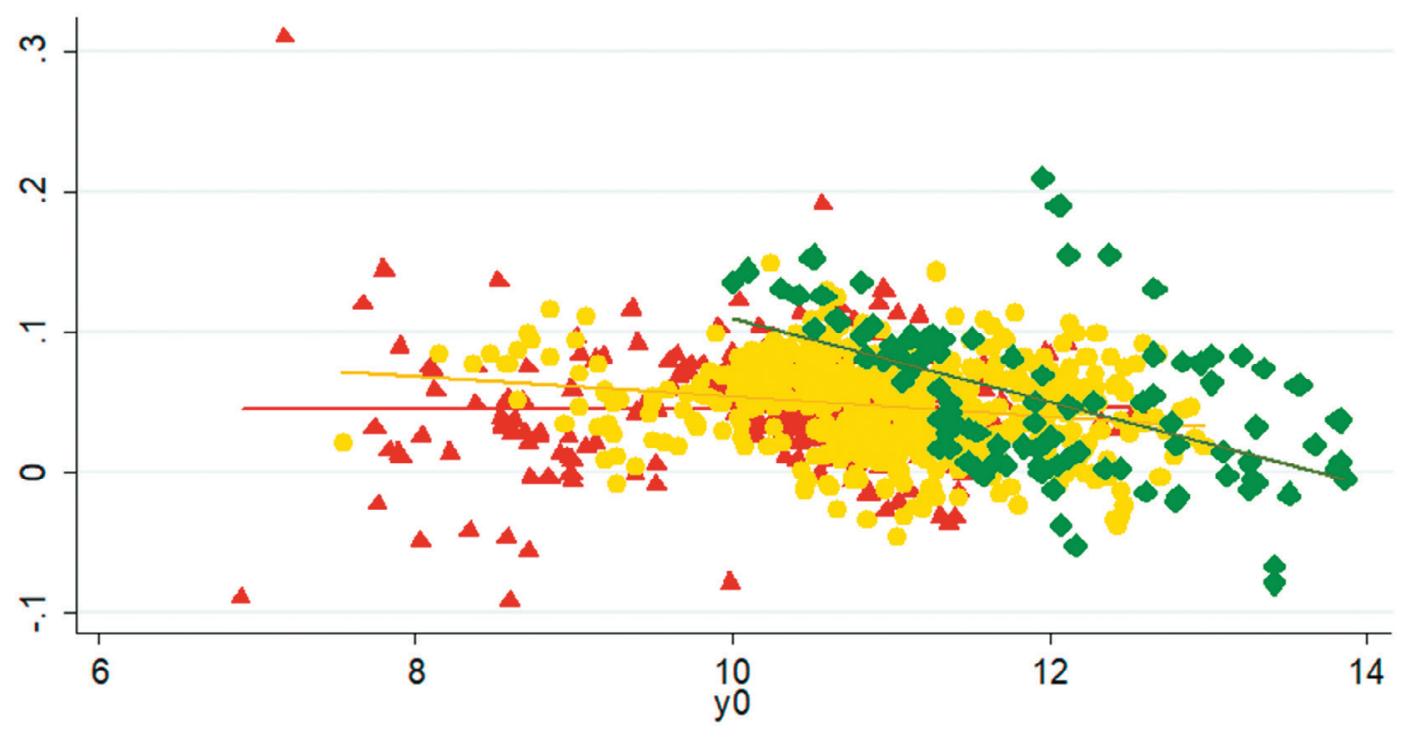

Fig. 4. Dependence of the average growth of GRP per capita over three years from its initial state (both variables in logarithms) (points and lines for poor, middle and rich regions are coloured red, yellow and green correspondingly)

other two groups of regions. While the dynamics of the poor and middle regions are more similar, there are still some differences.

As seen in Fig. 3, average growth of the rich regions sharply decreased in 2000-2008 and remains at a low level. The middle and poor regions in 2000-2005 showed insignificant growth (more moderate for the poor regions), a strong slowdown in 2005-2008, a slight recovery after the 2008 crisis and a new recession.

If we compare the graphs of the dependence of the average growth of GRP per capita over three years from its initial state (both variables are in logarithms) for three groups of regions (see Fig. 4), we can see that these dependences are negative in each case. The greatest slope is observed for rich regions, a lesser slope characterises the group of middle regions and an almost horizontal dependence takes place in the group of poor regions.

Thus, after a preliminary analysis, it is possible to assume that for the period of 2000-2017, the rates of beta-convergence (if this convergence occurs) for different groups of regions are not the same.

As a result, Hypothesis 1 was formulated for empirical testing.

Hypothesis 1: The speed of beta-convergence for rich, middle and poor groups of regions differ.

The following explains in more detail the choice of factors that affect economic growth in the selected groups of regions.

From the research perspective, one of the best papers that contains an overview of the variables affecting regional economic growth is [18].
A large but reliable number of variables is given in their paper. Inclusion of all these variables in the model is impossible, since there would be a problem of data multicollinearity hindering the identification of the influence of specific factors. Thus, how many explanatory variables should be included in the model? Doppelhofer and Miller [19] attempted to answer this question using the Bayesian Averaging of Classical Estimates (BACE) approach. The authors concluded that the optimal number of such variables is seven. The majority of researchers whose articles were mentioned in the literature review also included in their models a similar number of factors. I employ the recommended number of explanatory factors in my model as well and the variables selected for inclusion in the model are briefly described below.

The link between urban population or urbanisation level and economic growth was identified at the regional level for many countries [20-23], so the share of urban population is considered as one of the explanatory variables $\left(X_{1}=\right.$ urbanshare $)$.

Investments are a key growth factor in the neoclassical growth theory [24]. This variable is usually included in the model of economic growth that takes into account spatial effects $[25,26]$. The ratio of investment in fixed assets to real GRP $\left(X_{2}=i n v \_g p d\right)$ is also included into the present model. However, in Russia investments went mainly to the oil industry, so the effect of investments for poor, middle, rich regions may differ.

Another important growth factor according to this theory is the quality of human capital. The proportion of the population with higher educa- 
tion in the labour force ( $X_{3}=$ highed) is used as a characteristic of human capital.

The positive relationship between openness to foreign trade and economic growth was noted in a number of studies [27-31]. In this study, the ratio of exports and imports to the GRP of the region is analysed as an indicator of the openness of the region for trade $\left(X_{4}=\right.$ open $)$.

The infrastructure (especially the presence of highways) is very important for trade development, and for increase in mobility of the labour force. For example, EBRD noted Turkey's progress in the development of high-speed road construction, which led the country to economic growth by increasing the mobility of the workforce. Therefore, as one of the explanatory variables, the density of highways is used $\left(X_{5}=\right.$ road $)$.

The importance of accounting for sub-national institutions in the modelling of economic growth was noted by many researchers [8-10]. In studies on Russian data, the RA Expert index of investment risk $[8,10]$ is often used as such a factor, I also use this variable $\left(X_{6}-\right.$ risk).

The descriptive statistics of variables for different groups were compared (see Table 3).

There are disparities between poor, middle and rich groups of regions. For example, almost all mean values of variables characterising the attractiveness of the region, such as the share of urban population, the proportion of the population with higher education in the labour force, density of highways, investment activity, openness of the region for trade are much higher, and the index of investment risk is lower in the group of rich regions. The mean values for the group of middle regions for the majority of indicators are between groups of poor and rich regions, although the poor regions have a small advantage in terms of investments, the proportion of the population with higher education in the labour force, and the density of highways. It is natural to expect that the factors affecting the growth rate of the three identified groups of regions are different. Therefore, for the empirical verification, the following Hypothesis 2 is formulated:

Hypothesis 2: Factors affecting economic growth in poor, medium and rich regions are different.

Figure 2 demonstrates that the regions of each of the three groups are not randomly mixed, often they are adjacent to regions from the same group or to a whole group of regions from another group. Therefore (and this was noted by other authors, see above), the economic growth in the regions can be influenced not only by its internal factors, but also by growth in other re- gions, in particular, in the neighbouring ones. The importance of the condition of neighbouring regions for wage convergence in the Russian regions was demonstrated by [33], who discovered an empirical confirmation of regional wage convergence for the period of 1996-2013 and a positive influence for neighbouring regions in the economic growth. I also took into account the influence of neighbouring regions by introducing a spatial lag (details are given in the next section). Therefore, the last Hypothesis 3 for the empirical test is:

Hypothesis 3: Not only the internal factors, but also the adjacent regions' growth contribute to their growth of Russian regions.

In the next section, the model for testing these hypotheses will be described.

\section{Methodology}

To test main hypotheses, I use a slightly modernised basic model of Barro and Sala-i-Martin [32], dividing the regions into 3 groups and adding spatial effects.

$$
\begin{aligned}
& \frac{1}{3} \ln \frac{Y_{i(t+3)}}{Y_{i t}}=\beta^{p}\left(\begin{array}{c}
\ln Y_{i p} \\
0 \\
0
\end{array}\right)_{t}+\beta^{m}\left(\begin{array}{c}
0 \\
\ln Y_{i m} \\
0
\end{array}\right)_{t}+\beta^{r}\left(\begin{array}{c}
0 \\
0 \\
\ln Y_{i r}
\end{array}\right)_{t}+ \\
& +\rho^{p}\left(\begin{array}{c}
W \ln Y_{i p} \\
0 \\
0
\end{array}\right)_{t}+\rho^{m}\left(\begin{array}{c}
0 \\
W \ln Y_{i m} \\
0
\end{array}\right)_{t}+\rho^{r}\left(\begin{array}{c}
0 \\
0 \\
W \ln Y_{i r}
\end{array}\right)_{t}+ \\
& +\left(\begin{array}{c}
X_{i p} \\
0 \\
0
\end{array}\right)_{t} \theta^{p}+\left(\begin{array}{c}
0 \\
X_{i m} \\
0
\end{array}\right)_{t} \theta^{m}+\left(\begin{array}{c}
0 \\
0 \\
X_{i r}
\end{array}\right)_{t} \theta^{r}+\alpha_{i}+c_{t}+\left(\begin{array}{c}
\varepsilon_{i p} \\
\varepsilon_{i m} \\
\varepsilon_{i r}
\end{array}\right)_{t},(1)
\end{aligned}
$$

where $i=1, \ldots, 80$ is the number of the region, $i_{p}=1$, .., 27 is the numbers of poor regions, $i_{m}=28, \ldots, 72$ is the numbers of middle regions, $i_{r}=73, \ldots, 80$ is the numbers of rich regions, $t=2000, \ldots, 2014$ is the year, dependent variable $\frac{1}{3} \ln \frac{Y_{i(t+3)}}{Y_{i t}}$ is the of average 3-year GRP growth (in logarithm) for the period $[t, t+3], \ln Y_{i t}=\left(\begin{array}{l}\ln Y_{i p} \\ \ln Y_{i m} \\ \ln Y_{i r}\end{array}\right)_{t}$ is the logarithm of gross regional product per capita $(G R P)$ in basic prices of 2000 adjusted for different purchasing power (using the cost of the fixed basket of consumer goods $), \quad X=\left(X_{1}, \ldots, X_{6}\right)=\left(\begin{array}{l}X_{p} \\ X_{m} \\ X_{r}\end{array}\right)=\left(\begin{array}{ccc}X_{1 p} & \ldots & X_{6 p} \\ X_{1 m} & \ldots & X_{6 m} \\ X_{1 r} & \ldots & X_{6 r}\end{array}\right)$ is the matrix of explanatory variables, 
Descriptive statistics

\begin{tabular}{|c|c|c|c|c|c|c|}
\hline Variable & & Mean & Std. Dev. & Min & $\operatorname{Max}$ & Observations \\
\hline \multicolumn{7}{|c|}{ All Russia } \\
\hline \multirow{3}{*}{ Inpercap3aver } & overall & 0.03972 & 0.03718 & -0.092 & 0.31017 & $N=1200$ \\
\hline & between & & 0.01359 & -0.0004 & 0.07632 & $n=80$ \\
\hline & within & & 0.03464 & -0.1039 & 0.29925 & $T=15$ \\
\hline \multirow{3}{*}{ yo } & overall & 10.9278 & 0.96944 & 6.88969 & 13.8507 & $N=1200$ \\
\hline & between & & 0.82056 & 8.75503 & 13.1282 & $n=80$ \\
\hline & within & & 0.5238 & 8.67741 & 13.2327 & $T=15$ \\
\hline \multirow{3}{*}{ wyo } & overall & 10.91 & 0.35949 & 9.09412 & 11.749 & $N=1200$ \\
\hline & between & & 0.19572 & 9.91554 & 11.351 & $n=80$ \\
\hline & within & & 0.30228 & 10.0367 & 11.5801 & $T=15$ \\
\hline \multirow{3}{*}{ urbanshare } & overall & 0.69181 & 0.12664 & 0.259 & 1 & $N=1200$ \\
\hline & between & & 0.12678 & 0.2706 & 1 & $n=80$ \\
\hline & within & & 0.01227 & 0.64114 & 0.75048 & $T=15$ \\
\hline \multirow{3}{*}{ invgrp } & overall & 0.26048 & 0.1122 & 0.07847 & 1.07994 & $N=1200$ \\
\hline & between & & 0.07604 & 0.1364 & 0.52949 & $n=80$ \\
\hline & within & & 0.08291 & -0.0055 & 0.97774 & $T=15$ \\
\hline \multirow{3}{*}{ highed } & overall & 0.24263 & 0.05781 & 0.10586 & 0.5 & $N=1200$ \\
\hline & between & & 0.04382 & 0.1746 & 0.46107 & $n=80$ \\
\hline & within & & 0.038 & 0.125 & 0.37897 & $T=15$ \\
\hline \multirow{3}{*}{ road } & overall & 161.452 & 252.553 & 0.8 & 2199.77 & $N=1200$ \\
\hline & between & & 247.231 & 0.96 & 2105.78 & $n=80$ \\
\hline & within & & 58.0831 & -17.881 & 513.919 & $T=15$ \\
\hline \multirow{3}{*}{ open } & overall & 0.36024 & 0.47564 & 0 & 4.8401 & $N=1200$ \\
\hline & between & & 0.29894 & 0.03007 & 1.51859 & $n=80$ \\
\hline & within & & 0.37137 & -1.0026 & 3.68175 & $T=15$ \\
\hline \multirow{3}{*}{ risk } & overall & 0.2624 & 0.18613 & 0 & 1 & $N=1200$ \\
\hline & between & & 0.15222 & 0.0464 & 0.92286 & $n=80$ \\
\hline & within & & 0.10837 & -0.2509 & 0.89964 & $T=15$ \\
\hline \multicolumn{7}{|c|}{ Poor } \\
\hline \multirow{3}{*}{ Inpercap3aver } & overall & 0.03855 & 0.03763 & -0.092 & 0.31017 & $N=405$ \\
\hline & between & & 0.01465 & -0.0004 & 0.07304 & $n=27$ \\
\hline & within & & 0.03477 & -0.104 & 0.29809 & $T=15$ \\
\hline \multirow{3}{*}{ yo } & overall & 10.4344 & 0.92949 & 6.88969 & 12.5829 & $N=405$ \\
\hline & between & & 0.7345 & 8.75503 & 11.6915 & $n=27$ \\
\hline & within & & 0.58579 & 8.18407 & 12.7394 & $T=15$ \\
\hline \multirow{3}{*}{ wyo } & overall & 10.8296 & 0.39909 & 9.09412 & 11.4443 & $N=405$ \\
\hline & between & & 0.25507 & 9.91554 & 11.1047 & $n=27$ \\
\hline & within & & 0.31059 & 10.0081 & 11.4996 & $T=15$ \\
\hline \multirow{3}{*}{ urbanshare } & overall & 0.61281 & 0.11945 & 0.259 & 0.796 & $N=405$ \\
\hline & between & & 0.12102 & 0.2706 & 0.7664 & $n=27$ \\
\hline & within & & 0.01142 & 0.57321 & 0.64241 & $T=15$ \\
\hline \multirow{3}{*}{ invgrp } & overall & 0.26825 & 0.10868 & 0.07847 & 1.06685 & $N=405$ \\
\hline & between & & 0.07143 & 0.17782 & 0.4422 & $n=27$ \\
\hline & within & & 0.08298 & 0.02604 & 0.8929 & $T=15$ \\
\hline \multirow{3}{*}{ highed } & overall & 0.24424 & 0.05271 & 0.133 & 0.46 & $N=405$ \\
\hline & between & & 0.03666 & 0.18893 & 0.33567 & $n=27$ \\
\hline & within & & 0.03848 & 0.15537 & 0.38057 & $T=15$ \\
\hline \multirow{3}{*}{ road } & overall & 162.332 & 132.868 & 0.8 & 697 & $N=405$ \\
\hline & between & & 113.373 & 0.96 & 403.4 & $n=27$ \\
\hline & within & & 72.4284 & 10.3324 & 514.799 & $T=15$ \\
\hline
\end{tabular}




\begin{tabular}{|c|c|c|c|c|c|c|}
\hline Variable & & Mean & Std. Dev. & Min & Max & Observations \\
\hline \multirow{3}{*}{ open } & overall & 0.27648 & 0.43382 & 0.005 & 3.6809 & $N=405$ \\
\hline & between & & 0.22272 & 0.03007 & 1.05806 & $n=27$ \\
\hline & within & & 0.37459 & -0.6119 & 3.46329 & $T=15$ \\
\hline \multirow{3}{*}{ risk } & overall & 0.33628 & 0.24625 & 0 & 1 & $N=405$ \\
\hline & between & & 0.20546 & 0.04862 & 0.92286 & $n=27$ \\
\hline & within & & 0.14102 & -0.177 & 0.97353 & $T=15$ \\
\hline \multicolumn{7}{|c|}{ Middle } \\
\hline \multirow{3}{*}{ Inpercap3aver } & overall & 0.03979 & 0.03328 & -0.0541 & 0.15023 & $N=675$ \\
\hline & between & & 0.01158 & 0.01577 & 0.06228 & $n=45$ \\
\hline & within & & 0.03125 & -0.0611 & 0.13893 & $T=15$ \\
\hline \multirow{3}{*}{ yo } & overall & 11.0215 & 0.78379 & 7.52277 & 12.9616 & $N=675$ \\
\hline & between & & 0.62278 & 9.36098 & 12.2231 & $n=45$ \\
\hline & within & & 0.48428 & 9.14549 & 12.5158 & $T=15$ \\
\hline \multirow{3}{*}{ wyo } & overall & 10.947 & 0.33429 & 9.64323 & 11.749 & $N=675$ \\
\hline & between & & 0.14859 & 10.5166 & 11.351 & $n=45$ \\
\hline & within & & 0.30021 & 10.0737 & 11.5804 & $T=15$ \\
\hline \multirow{3}{*}{ urbanshare } & overall & 0.71927 & 0.10005 & 0.469 & 0.958 & $N=675$ \\
\hline & between & & 0.10043 & 0.51013 & 0.94387 & $n=45$ \\
\hline & within & & 0.01152 & 0.66861 & 0.75447 & $T=15$ \\
\hline \multirow{3}{*}{ invgrp } & overall & 0.24163 & 0.08628 & 0.08981 & 1.07994 & $N=675$ \\
\hline & between & & 0.04873 & 0.17694 & 0.40572 & $n=45$ \\
\hline & within & & 0.07155 & -0.0047 & 0.95889 & $T=15$ \\
\hline \multirow{3}{*}{ highed } & overall & 0.23507 & 0.04623 & 0.124 & 0.388 & $N=675$ \\
\hline & between & & 0.0284 & 0.1746 & 0.2992 & $n=45$ \\
\hline & within & & 0.03671 & 0.11974 & 0.35574 & $T=15$ \\
\hline \multirow{3}{*}{ road } & overall & 125.478 & 104.057 & 2.4 & 564 & $N=675$ \\
\hline & between & & 93.7759 & 2.78667 & 302.467 & $n=45$ \\
\hline & within & & 47.0816 & -0.922 & 389.145 & $T=15$ \\
\hline \multirow{3}{*}{ open } & overall & 0.3496 & 0.44905 & 0.01778 & 4.4604 & $N=675$ \\
\hline & between & & 0.26803 & 0.06066 & 1.32475 & $n=45$ \\
\hline & within & & 0.36235 & -0.7322 & 3.48525 & $T=15$ \\
\hline \multirow{3}{*}{ risk } & overall & 0.23096 & 0.13065 & 0 & 0.85176 & $N=675$ \\
\hline & between & & 0.09965 & 0.0464 & 0.57569 & $n=45$ \\
\hline & within & & 0.08572 & -0.1479 & 0.62139 & $T=15$ \\
\hline \multicolumn{7}{|c|}{ Rich } \\
\hline \multirow{3}{*}{ Inpercap3aver } & overall & 0.04324 & 0.05323 & -0.0792 & 0.20854 & $N=120$ \\
\hline & between & & 0.02066 & 0.01487 & 0.07632 & $n=8$ \\
\hline & within & & 0.04956 & -0.1003 & 0.18743 & $T=15$ \\
\hline \multirow{3}{*}{ yo } & overall & 12.0656 & 0.93429 & 9.99929 & 13.8507 & $N=120$ \\
\hline & between & & 0.8259 & 11.1447 & 13.1282 & $n=8$ \\
\hline & within & & 0.52061 & 10.817 & 13.1791 & $T=15$ \\
\hline \multirow{3}{*}{ wyo } & overall & 10.9739 & 0.30749 & 10.1767 & 11.4324 & $N=120$ \\
\hline & between & & 0.11599 & 10.8171 & 11.1214 & $n=8$ \\
\hline & within & & 0.28753 & 10.2688 & 11.3606 & $T=15$ \\
\hline \multirow{3}{*}{ urbanshare } & overall & 0.80394 & 0.13509 & 0.599 & 1 & $N=120$ \\
\hline & between & & 0.14254 & 0.62053 & 1 & $n=8$ \\
\hline & within & & 0.01797 & 0.76781 & 0.86261 & $T=15$ \\
\hline \multirow{3}{*}{ invgrp } & overall & 0.34029 & 0.18954 & 0.10771 & 0.95173 & $N=120$ \\
\hline & between & & 0.14687 & 0.1364 & 0.52949 & $n=8$ \\
\hline & within & & 0.12998 & 0.07428 & 0.82255 & $T=15$ \\
\hline
\end{tabular}

Table 3 on the next page end 
Table 3 end

\begin{tabular}{|l|c|c|c|c|c|c|}
\hline Variable & & Mean & Std. Dev. & Min & Max & Observations \\
\hline \multirow{3}{*}{ highed } & overall & 0.27974 & 0.10202 & 0.10586 & 0.5 & $N=120$ \\
\cline { 2 - 7 } & between & & 0.09826 & 0.17647 & 0.46107 & $n=8$ \\
\cline { 2 - 7 } & within & & 0.04345 & 0.16212 & 0.39908 & $T=15$ \\
\hline \multirow{4}{*}{ road } & overall & 360.834 & 688.448 & 0.9 & 2199.77 & $N=120$ \\
\cline { 2 - 7 } & between & & 730.099 & 1.07333 & 2105.78 & $n=8$ \\
\cline { 2 - 7 } & within & & 60.2259 & 181.501 & 595.501 & $T=15$ \\
\hline \multirow{3}{*}{ risk } & overall & 0.70278 & 0.59635 & 0 & 4.8401 & $N=120$ \\
\cline { 2 - 7 } & between & & 0.45923 & 0.12941 & 1.51859 & $n=8$ \\
\cline { 2 - 7 } & within & & 0.41176 & -0.66 & 4.02429 & $T=15$ \\
\cline { 2 - 7 } & overall & 0.18987 & 0.13046 & 0 & 0.73485 & $N=120$ \\
\cline { 2 - 7 } & between & & 0.09412 & 0.05614 & 0.31412 & $n=8$ \\
\cline { 2 - 7 } & within & & 0.09593 & 0.00041 & 0.61061 & $T=15$ \\
\hline
\end{tabular}

( $X_{1}=$ urbanshare, $X_{2}=$ inv $g d p, X_{3}=$ highed, $X_{4}=$ = open, $X_{5}=$ road, $X_{6}=$ risk), $W$ is the binary contiguity weighting matrix, $\alpha_{i}$ is the individual fixed or random effect, and $c_{\mathrm{t}}$ is the time effect, $\rho^{p}, \rho^{m}, \rho^{r}$ are spatial correlation coefficients, $\beta^{p}, \beta^{m}, \beta^{r}, \theta^{p}=$ $\left(\theta_{1}^{p}, \ldots, \theta_{6}^{p}\right)^{\prime}, \theta^{m}=\left(\theta_{1}^{m}, \ldots, \theta_{6}^{m}\right)^{\prime}, \theta^{r}=\left(\theta_{1}^{r}, \ldots, \theta_{6}^{r}\right)^{\prime}$ are estimated coefficients, $\varepsilon_{i t}$ is a normally distributed error term.

The main modification of this model is splitting of all independent variables in three parts (that correspond to poor, middle and rich group of regions) and the inclusion of spatial lags created with the help of the weighting matrix $W$,

$$
W=\left(\begin{array}{cccc}
0 & w_{12} & \ldots & w_{1 n} \\
w_{21} & 0 & \ldots & w_{2 n} \\
\vdots & \vdots & \ddots & \vdots \\
w_{n 1} & w_{n 2} & \ldots & 0
\end{array}\right)
$$

where $w_{i j}=1$ if regions $i$ and $j$ have a joint boundary and 0 otherwise. After that, matrix is line-normalised, so it accounts for the weights.

Spatial lag $W \ln Y_{i t}=\left(\begin{array}{l}W \ln Y_{i p} \\ W \ln Y_{i m} \\ W \ln Y_{i r}\end{array}\right)_{t}$ was split into three parts like all other explanatory variables; it reflect the mutual influence of regions on each other.

The three main research hypotheses may be formally tested (see the details below).

Hypothesis 1. The speed of beta-convergence for rich, middle and poor groups of regions differ.

Formal main and alternative hypotheses:

$\mathrm{H}_{0}^{1}: \beta^{p}=\beta^{m}=\beta^{r}$;

$\mathrm{H}_{1}^{1}: \beta^{p} \neq \beta^{m}$ or $\beta^{p} \neq \beta^{r}$ or $\beta^{m} \neq \beta^{r}$ (corresponds to Hypothesis 1).

Hypothesis 2: Factors affecting economic growth in poor, middle and rich regions are different.
Formal main and alternative hypotheses:

$\mathrm{H}_{0}^{2}: \theta_{j}^{p}=\theta_{j}^{m}=\theta_{j}^{r}, j=1, \ldots, 6$;

$\mathrm{H}_{1}^{2}: \exists j: \theta_{j}^{p} \neq \theta_{j}^{m}$ or $\theta_{j}^{p} \neq \theta_{j}^{r}$ or $\theta_{j}^{m} \neq \theta_{i r}$ (corresponds to Hypothesis 2).

Hypothesis 3: The growth of Russian regions is affected not only by their internal factors, but also by the growth of other Russian regions.

Formal main and alternative hypotheses:

$\mathrm{H}_{0}^{3}: \rho^{p}=\rho^{m}=\rho^{r}$;

$\mathrm{H}_{1}^{3}: \rho^{p} \neq \rho^{m}$ or $\rho^{p} \neq \rho^{r}$ or $\rho^{m} \neq \rho^{r}$ (corresponds to Hypothesis 3).

A large number of variables (and estimated coefficients) may also lead to the problem of the data multicollinearity, whose consequences are the insignificance of the coefficients at many factors and instability of estimations. To raise the efficiency of the estimates, the number of estimated parameters was reduced using the following procedure. Hypotheses about the equality of coefficients for the same factors were tested, namely

$$
\mathrm{H}_{0}: \theta_{j}^{p}=\theta_{j}^{m}=\theta_{j}^{r}, j=1, \ldots, 6 .
$$

If the corresponding restrictions were not rejected, they were incorporated into the regression equation replacing the corresponding set of three variables (for example $X_{1}^{p}, X_{1}^{m}, X_{1}^{r}$ ) with one variable (in this case $X_{1}$ ). In this case, the dependence on the corresponding factor for all three groups of regions is unified. If the corresponding hypothesis was rejected, then the dependence on the corresponding factor for the poor, middle and rich regions was not unified.

The estimation results are presented in the next section.

\section{Estimation Results}

\section{Main Results}

In each case, I estimated pooled, fixed and random effect models and performed necessary tests 
to choose the best one. In all cases, it is the model with fixed effects. The final estimation results are given in Table 4.

Model 1 contains the full set of variables. After that, I tested hypotheses (2) about the common dependence for each set of triplet variables.
Restrictions (2) were not rejected only for the variables urbanshare, highed, road and open. Corresponding restrictions were incorporated in Model 2.

The results of Model 2 estimation can be interpreted as follows:

Table 4

Estimation results

\begin{tabular}{|c|c|c|c|c|}
\hline Model & Model 1 & Model 2 & Model 3 & Model 4 \\
\hline Number of the groups of regions & 3 & 3 & 3 & 1 \\
\hline Incorporated restrictions & No & Yes & Yes & \\
\hline Spatial lag & Yes & Yes & No & Yes \\
\hline urbansharep & -0.039 & & & \\
\hline urbansharem & -0.06 & & & \\
\hline urbansharer & 0.203 & & & \\
\hline urbanshare & & 0.004 & -0.022 & -0.086 \\
\hline$i n v \_g r p p$ & $-0.109^{* * *}$ & $-0.109^{* * *}$ & $-0.107^{* * *}$ & \\
\hline inv_grpm & $-0.031^{*}$ & $-0.033^{* *}$ & $-0.031^{*}$ & \\
\hline$i n v \_g r p r$ & $0.066^{* * *}$ & $0.055^{* * *}$ & $0.048^{* *}$ & \\
\hline invgrp & & & & $-0.022^{* *}$ \\
\hline highedp & 0.056 & & & \\
\hline highedm & 0.03 & & & \\
\hline highedr & 0.037 & & & \\
\hline highed & & 0.045 & 0.045 & $0.065^{* *}$ \\
\hline roadp & 0 & & & \\
\hline roadm & 0 & & & \\
\hline roadr & 0 & & & \\
\hline road & & 0 & 0 & 0 \\
\hline riskp & $0.017^{*}$ & $0.017^{*}$ & $0.018^{*}$ & \\
\hline riskm & $0.034^{* * *}$ & $0.033^{* * *}$ & $0.032^{* * *}$ & \\
\hline riskr & $-0.126^{* * *}$ & $-0.120^{* * *}$ & $-0.114^{* * *}$ & \\
\hline risk & & & & $0.024^{* * *}$ \\
\hline Openp & 0.004 & & & \\
\hline Openm & $0.005^{* *}$ & & & \\
\hline Openr & 0.004 & & & \\
\hline Open & & $0.005^{* *}$ & $0.004^{* *}$ & 0.002 \\
\hline$y 0 p$ & -0.001 & 0 & 0.003 & \\
\hline$y 0 m$ & $-0.006^{* *}$ & $-0.006^{* *}$ & -0.003 & \\
\hline$y 0 r$ & $-0.016^{*}$ & $-0.021^{* * *}$ & $-0.037^{* * *}$ & \\
\hline$y 0$ & & & & $-0.006^{* * *}$ \\
\hline$w b y 0 p$ & $0.015^{* * *}$ & $0.014^{* * *}$ & & \\
\hline wby0m & $0.010^{* * *}$ & $0.010^{* * *}$ & & \\
\hline wby0r & $-0.035^{* *}$ & $-0.025^{*}$ & & \\
\hline wby0 & & & & $0.009^{* * *}$ \\
\hline Year dummies & Yes & Yes & Yes & Yes \\
\hline Number of observations & 1200 & 1200 & 1200 & 1200 \\
\hline Number of groups & 80 & 80 & 80 & 80 \\
\hline $\begin{array}{l}F \text {-statistics for testing hypotheses that all coefficients are } \\
\text { equal to } 0 \text { and } p \text {-value }\end{array}$ & $36.08(0.000)$ & $45.79(0.000)$ & $\begin{array}{c}49.32 \\
(0.000) \\
\end{array}$ & $47.88(0.000)$ \\
\hline$R_{\text {within }}^{2}$ & 0.5589 & 0.5576 & 0.5492 & 0.4896 \\
\hline $\begin{array}{l}\text { F-statistics for testing hypotheses that all fixed effects are } \\
\text { equal (H0: the pooled model is better) and } p \text {-value }\end{array}$ & $4.42(0.000)$ & $4.86(0.000)$ & $4.87(0.000)$ & $4.28(0.000)$ \\
\hline $\begin{array}{l}\text { Ch2-statistics in Hausman test (H0: random effects model } \\
\text { is better) and } p \text {-value }\end{array}$ & $94.46(0.000)$ & $136.06(0.000)$ & $89.98(0.000)$ & $44.75(0.000)$ \\
\hline
\end{tabular}


1) All hypotheses received empirical confirmation.

2) Convergence or divergence has not been found for poor regions. Only the middle and rich regions are characterised by convergence, and the speed of convergence in the rich regions is higher. This result is similar to the results obtained by Solanko [1] and Kholodilin, Oshchepkov and Siliverstovs [3].

3) The situation in neighbouring regions affects all regions. The better the situation in neighbouring regions, the slower rich regions are growing. In poor and middle regions, we have the opposite tendency, as they benefit with the growth of neighbouring regions. For example, a well-developed Kaluga oblast is located near Moscow oblast. As the labour force, housing and rent in Kaluga oblast are much cheaper than in Moscow, many manufacturing enterprises, especially mechanical engineering, are transferred to Kaluga oblast. Due to this, Kaluga oblast is developing faster than Moscow oblast and is pulling some resources onto itself.

4) The share of urban population does not influence economic growth. This can be explained by the presence of two opposite trends: on the one hand, it is usually easier to find job in a city; on the other hand, for single-industry towns, of which there are more than 300 in Russia, the situation changes to the opposite when the city-forming enterprise closes.

5) Investments in the rich regions stimulate their economic growth, while the opposite effect is observed for the poor and middle regions (apparently, investments are inefficiently used).

6) The growth rate is not related to the share of labour force with higher education.

7) High density of highways does not stimulate economic growth.

8) Only the rich regions are characterised by the effect of the economic risk degree on the growth rate that meets the expectations (the lower the risk, the higher the growth). The effect is opposite for the middle and poor regions: those regions where the risk level is higher grow faster. A separate study is needed to get an insight into this phenomenon.

9) The region's openness towards expert/import stimulates the growth rate.
This question clearly deserves a more detailed study related to the structure of exports and imports, as, for example, in the article [34].

\section{Consequences of the Incorrect Specification}

In order to estimate the consequences of the incorrect specification, two additional models were examined. Model 3 differs from Model 2 by the absence of spatial lags reflecting the mutual influence of regions, and in Model 4, a single dependence is used for all Russian regions (they are not divided into 3 groups). The results of the estimation of Model 3 indicate that neglecting of the spatial effects may lead to a twofold overestimation of the beta coefficient, which determines the speed of conditional convergence for the rich regions. According to Model 4, while modelling a unique dependence for all groups of regions, the difference in the influence of the same factors on the growth of regions of different groups was not detected for the variables that characterise investment activity and investment risk.

\section{Conclusion}

In this paper, Russian regional data were used to analyse gross regional product per capita convergence or divergence for poor, middle and rich Russian regions in the period 2000-2017.

With the help of a specially developed spatial-econometric model, which took into account the division of regions into three groups and the mutual influence of the regions on each other, significant differences between the identified groups of regions were revealed.

The convergence process is taking place in rich and middle regions (much faster in the rich regions than in the middle ones). Only rich regions have negative spillovers from growth of neighbouring regions. At the same time, poor and middle regions have positive spillovers, benefiting from positive changes in neighbouring regions.

According to the obtained results, unfortunately, investments in poor and middle regions are not effective and do not stimulate economic growth (the situation is opposite in rich regions). In order to stimulate economic growth in poor and middle regions, it is necessary to increase the openness of regional economies, export and import activity.

\section{References}

1. Solanko, L. (2008). Unequal fortunes: a note on income convergence across Russian regions. Post-Communist Economies, 20(3), 287-301. DOI: 10.1080/14631370802281399.

2. Gluschenko, K. P. (2012). Myths about beta-convergence. William Davidson Institution Working Paper no. $1040,21$.

3. Kholodilin, K. A., Oshchepkov, A. \& Siliverstovs, B. (2012). The Russian regional convergence process: Where is it leading? Eastern European Economics, 50(3), 5-26. DOI: 10.2753/EEE0012-8775500301. 
4. Vakulenko, E. (2015). Analysis of the relationship between regional labour markets in Russia using Okun's model. Prikladnaya ekonometrika [Applied Econometrics], 40(4), 28-48 (In Russ.).

5. Guriev, S. \& Vakulenko, E. (2012). Convergence between Russian Regions. Center for Economic and Financial Research (CEFIR) no. w0180, 82.

6. Berkowitz, D. \& DeJong, D. N. (2005). Entrepreneurship and Post-socialist Growth. Oxford Bulletin of Economics and Statistics, 67, 25-46.

7. Berkowitz, D. \& DeJong, D. N. (2011). Growth in post-Soviet Russia: A tale of two transitions. Journal of Economic Behavior \& Organization, 79(1-2), 133-143.

8. Leonard, C. S., Nazarov, Z. \& Vakulenko, E. S. (2016). The impact of sub-national institutions. Economics of Transition, 24(3), 421-446. DOI: 10.1111/ecot.12095.

9. Alexeev, M. \& Chernyavskiy, A. (2015). Taxation of natural resources and economic growth in Russia's regions. Economic Systems, 39(2), 317-338. DOI: 10.1016/j.ecosys.2014.10.007.

10. Libman, A. (2013). Natural resources and sub-national economic performance: Does sub-national democracy matter? Energy Economics, 37, 82-99. DOI: 10.1016/j.eneco.2013.02.003.

11. Vainberg, A. \& Rybnikova T. (2006). Institutsionalnye i Geograficheskie Faktory Razvitiya Regionov Rossii [Institutional and Geographic Factors of Development of Russian Regions]. Mimeo. Retrieved from: http://data.cemi.rssi.ru/isepweb/anal/ geofact.htm (Date of access: 10.12.2021) (In Russ.)

12. Elhorst, J. P. (2014). Spatial econometrics. From Cross-Sectional Data to Spatial Panels. Series: Springer Briefs in Regional Science, 119. DOI: 10.1007/978-3-642-40340-8.

13. Buccellato, T. (2007). Convergence across Russian regions: a spatial econometrics approach. UCL, Economics Working Paper 72, 27.

14. Lugovoy, O., Dashkeyev, V., Mazayev, I., Fomchenko, D., Polyakov. E. \& Hecht, A. (2007). Analysis of Economic Growth in Regions: Geographical and Institutional Aspect. Consortium for Economic Policy Research and Advice. Moscow: IET, 130 .

15. Kolomak, E. (2011). Spatial Externalities as a Source of Economic Growth. Regional Research of Russia, 2(1), 114119). Moscow: Springer.

16. Bufetova, A. N. (2017). Trends in the concentration of economic activity and disparities in Russia's spatial development. Regional Research of Russia, 7(2), 120-126. DOI: 10.1134/S2079970517020022

17. Zubarevich, N. V. \& Gorina, E. A. (2015). Sotsialnye raskhody $v$ Rossii: federalnyy i regionalnyy byudzhety [Social expenditures in Russia: federal and regional budgets]. Moscow: Higher School of Economics, 62. (In Russ.)

18. Barro, R. J. \& Sala-i-Martin, X. I. (2004). Economic growth. Cambridge, MA: MIT Press, 625.

19. Doppelhofer, G. \& Miller, R. I. (2004). Determinants of long-term growth: A Bayesian averaging of classical estimates (BACE) approach. American economic review, 94(4), 813-835.

20. Spence, M., Annez, P. C. \& Buckley, R. M. (Eds.). (2009). Urbanization and Growth: Commission on Growth and Development. World Bank, 255.

21. Turok, I. \& McGranahan, G. (2013). Urbanization and economic growth: the arguments and evidence for Africa and Asia. Environment and Urbanization, 25(2), 465-482. DOI: 10.1177/0956247813490908.

22. Chen, M., Zhang, H., Liu, W. \& Zhang, W. (2014). The global pattern of urbanization and economic growth: evidence from the last three decades. PloS ONE, 9(8), e103799. DOI: 10.1371/journal.pone.0103799.

23. Castells-Quintana, D. (2017). Malthus living in a slum: Urban concentration, infrastructure and economic growth. Journal of Urban Economics, 98, 158-173. DOI: 10.1016/j.jue.2016.02.003.

24. Solow, R. M. (1956). A contribution to the theory of economic growth. The Quarterly Journal of Economics, 70(1), $65-94$.

25. Nwaogu, U. G. (2012). Essays on spatial analysis of foreign direct investment and economic growth determinants in developing countries. Western Michigan University, 135.

26. Huang, H. \& Wei, Y. D. (2016). Spatial inequality of foreign direct investment in China: Institutional change, agglomeration economies, and market access. Applied Geography, 69, 99-111. DOI: 10.1016/j.apgeog.2014.12.014.

27. Harrison, A. (1996). Openness and growth: A time-series, cross-country analysis for developing countries. Journal of Development Economics, 48(2), 419-447.

28. Sachs, J. D., Warner, A., Aslund, A. \& Fischer, S. (1995). Economic reform and the process of global integration. Brookings Papers on Economic Activity, 26(1), 1-118.

29. Yanikkaya, H. (2003). Trade openness and economic growth: a cross-country empirical investigation. Journal of Development economics, 72(1), 57-89. DOI: 10.1016/S0304-3878(03)00068-3.

30. Wacziarg, R. \& Welch, K. H. (2008). Trade liberalization and growth: New evidence. The World Bank Economic Review, 22(2), 187-231. DOI: 10.1093/wber/lhn007.

31. Huchet-Bourdon, M., Le Mouël, C. \& Vijil, M. (2018). The relationship between trade openness and economic growth: Some new insights on the openness measurement issue. The World Economy, 41(1), 59-76. DOI: 10.1111/twec.12586.

32. Barro, R. J. \& Sala-i-Martin, X. (1992). Convergence. Journal of political Economy, 100(2), 223-251.

33. Ivanova, V. I. (2017). Spatial Convergence of Real Wages in Russian Cities. The Annals of Regional Science, 61(1), 1-30. DOI: 10.1007/s00168-017-0855-0. 
34. Kadochnikov, S. M. \& Fedyunina, A. (2018). Explaining The Performance of Russian Export: What Role Does the Hard and Soft Infrastructure Play? International Journal of Economic Policy in Emerging Economies, 11(6), 541-559. DOI: 10.1504/IJEPEE.2018.095930.

\section{About the Author}

Olga A. Demidova - Cand. Sci. (Phys.-Math.), Associate Professor, Department of Applied Economics, National Research University "Higher School of Economics"; Scopus Author ID: 6602926736; https://orcid.org/0000-0001-52013207, (11, Pokrovskiy Boul., Moscow, 109028, Russian Federation; e-mail: demidova@hse.ru).

\section{Информация об авторе}

Демидова Ольга Анатольевна - кандидат физико-математических наук, доцент, Департамент прикладной экономики, Национальный исследовательский университет «Высшая школа экономики»; Scopus Author ID: 6602926736; https://orcid.org/0000-0001-5201-3207 (Российская Федерация, 109028, г. Москва, Покровский бульвар, 11; e-mail: demidova@hse.ru).

Дата поступления рукописи: 20.03.20

Прошла рецензирование: 11.06 .20

Принято решение о публикации: 24.09.2021.

Received: 20 Mar 2020.

Reviewed: 11 Jun 2020.

Accepted: 24 Sep 2021. 